\title{
Settlement Behaviour of Soft Clay Bed Reinforced with Stone Column under Sustained Loading
}

\author{
Sharad Kumar Soni, P.K. Jain, Rakesh Kumar
}

\begin{abstract}
This research paper investigates the behaviour of soft clay reinforced with stone column under sustained loading. Experiments were conducted in the laboratory on stone column reinforced prepared soft soil bed of kaolin having strength of 7.5 $\mathrm{kPa}$ with aggregate of size 2.5 to $10 \mathrm{~mm}$ as column material. The stone column with four diameters of 38.1, 50.8, 63.5 and $76.2 \mathrm{~mm}$ were constructed which correspond to low to high area replacements ratios (i.e. $6.93 \%$ - 26.49\%). The plain and reinforced soft clay beds were subjected to a sustained load of 150, 200, 250 and $300 \mathrm{kPa}$ where each applied load has been maintained for 24 hours and the settlement behavior of composite ground was taken into account. The test results represent the settlement of reinforced soil bed decreases with increase of column diameters. The settlement reduction ratio is a measure of ground improvement which increases with area replacement ratio. The experimental and theoretical results values were compared as per IS15284 (Part 1): 2003 with reference of stress concentration ratio ' $n$ '(The ratio of stress in the column to the stress of surrounding ground area). The \% variation in theoretical and experimental results is in the range of $\pm 50 \%$ and therefore the theoretical procedure needs to be revised.
\end{abstract}

Keywords: soft clay, stone column, compactive effort, replacement method, settlement reduction ratio

\section{INTRODUCTION}

The embankments of bridges, rail and road, fluid storage vessels where the settlement is higher, the stone column technique is credible than pile in terms of low cast and time of establishment as a substructure. The ground which treated with stone columns would have high bearing capacity, low settlement downs and possible free drainage. The suitable soils for this technique are loose sands to soft clays. The lab studies reported the effect of related phases like ratio of area

Revised Manuscript Received on December 30, 2019.

* Correspondence Author

Sharad Kumar Soni*, Research Scholar, Department of Civil Engineering, Maulana Azad National Institute of Technology, Bhopal, India. Email: ssoni1979@yahoo.co.in

Dr. P.K.Jain, Professor, Department of Civil Engineering, Maulana Azad National Institute of Technology, Bhopal, India.. Email: pkjain10@rediffmail.com

Dr. Rakesh Kumar, Associate Professor, Department of Civil Engineering, Maulana Azad National Institute of Technology, Bhopal, India. Email: rakesh20777@gmail.com

(C) The Authors. Published by Blue Eyes Intelligence Engineering and Sciences Publication (BEIESP). This is an open access article under the CC BY-NC-ND license (http://creativecommons.org/licenses/by-nc-nd/4.0/) replacement, length to diameter, space to diameter on bearing capacity of reinforce soil bed.

Ambily and Gandhi [3] investigate the stone column behavior where the column spacing, strength and moisture content of surrounding soil taken as variable in study. They concise that when loading provided to the column area alone, the bulging will occur from a height of 0.5 to 1 times the column diameter from the top. Ambily and Gandhi [4] also probe the unit cell notion for single and group of columns in load variations. The results confirm that unit cell simulation of single column in laboratory to an interior column in field could be carried out. Isaac and Girish [15] investigated the material suitability for stone columns. The five different materials selected for study is found in deceasing order of suitability for load deformation behavior are stones, gravels, quarry dust, river sand, and sea sand. Further, conclusion was that with decreasing in spacing between stone columns the effectiveness increases. Babu et al. [5] suggested an alternate approach to enhance the load bearing capacity of stone columns by providing vertical circumferential nails where no. of plate load tests were carried on test tanks. The vertical nails gives the confining effect to stone column which reduce the bulging from 3 to 4 diameter length from top. Babu et al. [5] explained an approach to imrove the load carrying capacity of stone columns by providing vertical circumferential nails by conducting a no. of plate load tests in laboratory from unit cell notion. The vertical nails gives the confining effect to stone column which reduce the bulging from 3 to 4 diameter length from top. Cimentada et al. [12] studied the deformation and radial consolidation of end bearing stone columns in a modified Rowe-Barden oedometric cell with two different cells to column diameters ratios and reported that consolidation coefficient will be higher when replacement area increases. Shivshanker et al. [26] Investigated the behaviour of stone columns in layered soil bed and found that weak soil in upper layer has influence on load bearing capacity, bulging and stiffness of stone columns. Shahu and Reddy [27] conducted full drained, load-control model experiments for floating type stone column group foundation and found that bending of a column is dependent on the position of a column in the group, where the ratio of area replacement, $\mathrm{l} / \mathrm{d}$ ratio, over consolidation ratio, relative stiffness and the stress ratio affects the repercussion of stone column group foundation

Kumar and Jain [18] reported that stone columns or granular piles can be used to improve the behaviour of black cotton or soft expansive soil. Dehariya et al.

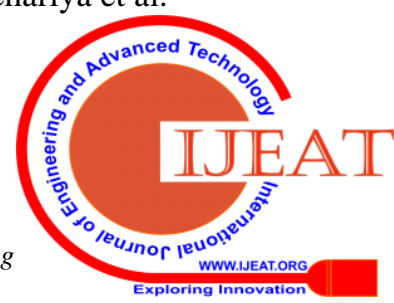


[13] studied the load settlement pattern of granular column in the conditions of saturated and unsaturated soil. The results represent that, at lower water content soil offers high load bearing resistance. Rajput et al. [23] have also selected black cotton soil for studying the efficiency of granular sand piles. They concluded that length to diameter ratio equals to 5 which may be an ideal sand pile length to instate the benefits of installing the sand piles and the load carrying capacity of sand pile increases with decrease of spacing.

Settlement estimation for soil reinforced with stone column was given by Priebe in 1976[22] through semi empirical equations. Solution was given for end-bearing type columns assuming column material was incompressible with both soil and column bulk densities were neglected. Priebe assumed a rational value of $1 / 3$ for Poisson's ratio of the soil. Aboshi et al. [1] has given the equation for Settlement reduction ratio by assuming uniform vertical stress thought the column length. Balaam and Booker [6] has given the solution for yield of stone column. The principal direction was assumed vertical and the rigid base was assumed smooth. The main parameters affecting settlement were found to be column spacing ratio, angle of shearing resistance of stone column, dilatancy angle, load level, modular ratio and Poisson's ratio of the clay. Barksdale and Bachus [7] has given the similar equation as given in IS15284 (Part-1): 2003[17]. Settlement estimation for soil with stone column was given by Priebe in 1976[22] through semi empirical equations. Solution was given for end-bearing type columns assuming column material was incompressible with both soil and column bulk densities were neglected. Priebe assumed a rational value of $1 / 3$ for Poisson's ratio of the soil. Aboshi et al.[1] has given the equation for Settlement reduction ratio by assuming uniform vertical stress thought the column length. Balaam and Booker [6] has given the solution for yield of stone column. Principal direction was assumed vertical and the rigid base was assumed smooth. The main parameters affecting settlement were the column spacing ratio, angle of friction of stone column material, dilatancy angle, load level, modular ratio and Poisson's ratio of the clay. Barksdale and Bachus [7] has given the similar equation as given in IS15284 (Part-1): 2003[17].

IS 15284 suggests stress concentration ratio 'n' to be taken between 2.5 to 5; whereas Barksdale and Bachus have taken it from 1.5 to 5 . The value 5 is corresponding to area replacement ratio, ' $\mathrm{a}_{\mathrm{s}}$ ' of about $40 \%$ and 1.5 is for ' $\mathrm{a}_{\mathrm{s}}$ ' equal to about 7\%. Baumann and Bauer [8] suggested equations for estimating immediate and consolidation settlement of stone column reinforced soft soil. A set of curves have been provided for estimation of immediate settlement. Van Impe and De Beer [28] suggested a new method for analysis of the settlement response of granular column. Alamgir et al. [2] presented a theoretical solution for settlement of a reinforced flexible (such as flexible raft or embankment) foundation with end bearing stone columns. Madhav and Miura [19] studied the effect of dilation angle of stone columns and found that settlement reduction ratio increases even with a dilation of $0.5 \%$ of the stone column material. Borges et al. [10] suggested a new design form for soft soil embankments reinforced with stone columns with finite element analysis. "Unit cell" concept was used. It was concluded that, area replacement ratio and compressibility ratio are the major factors affecting the settlement of treated ground. Ellouze et al. [14] analyzed the settlement of stone column reinforced foundation and outlined inconsistencies in Priebe's approach. Zhang et al. [29] has given an analytical form for the settlement response reinforced stone columns in soft soil. Equal strain was assumed, column was assumed to be an elastic material, confining pressure of the soil was assumed to be earth pressure at rest. Rangeard et al. [25] investigated the sand column behavior through laboratory experimental procedure. They compared the effect of the displacement and replacement method on settlement of soft soil reinforced soils. The results show settlement reduction rate by replacement method is more than that by displacement method. The displacement method was found better than the replacement method due to added advantage of radial densification in surrounding soil during column installation. Chandrawanshi [11] has developed design charts to obtain area replacement ratio for the desired settlement reduction. These charts are developed for very soft soils of undrained shear strength between 2.5 to $7.5 \mathrm{kPa}$ reinforced with stone column and subjected to sustained pressure in the range of $100-200 \mathrm{kPa}$. The compactive efforts for installing the stone column were in the range of $22-224 \mathrm{~kJ} / \mathrm{m}^{3}$ using replacement method. One such chart is shown in Fig.1.

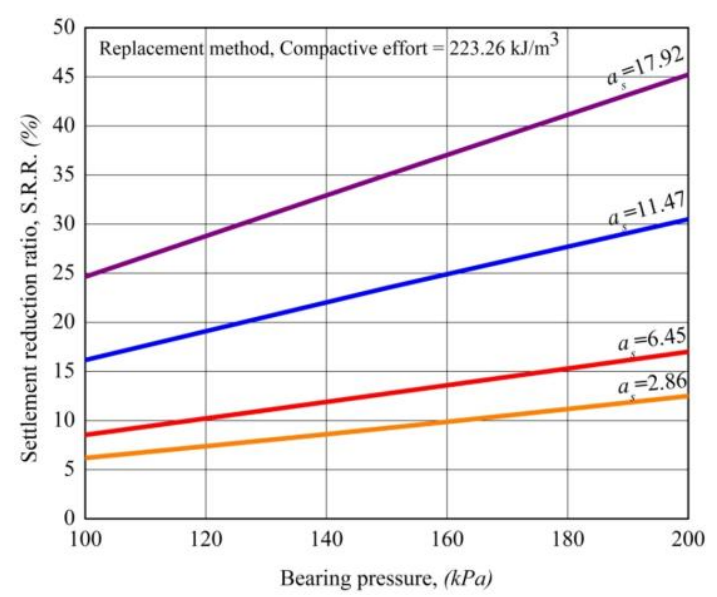

Fig.1. Design chart for selecting size of stone column for desired settlement reduction (Chandrawanshi 2018).

The estimation of consolidation settlement of soft soils, reinforced with stone column under sustained loading of different magnitude is greatly influenced by the stiffness of the column material. The task will be more complicated where geogrid are used to further enhance the effectiveness of the stone column. The present work is an attempt to study the settlement behavior of soft soil reinforced with stone column of varying diameters subjected to different pressures. The test beds of soft soil were prepared in which stone columns of different diameters were installed. The composite ground was subjected to sustained pressure to study the settlement behavior. The results of the tests have been compared with the theoretical solutions given in the literature to examine the applicability of these solutions for further refining the prediction settlement of stone column reinforced soils. 


\section{MATERIAL PROPERTIES} The basalt rock stones were used as a material for column, which were taken from particle size between $2.5 \mathrm{~mm}$ and 10 $\mathrm{mm}$.

\begin{tabular}{|l|l|}
\hline Property & Value \\
\hline Specific Gravity & 2.62 \\
\hline Liquid Limit & $27 \%$ \\
\hline Plastic Limit & $18 \%$ \\
\hline Plasticity Index & $9 \%$ \\
\hline Classification(IS:1498-1970) & CL \\
\hline \multicolumn{2}{|c|}{ Standard Proctor Test } \\
\hline Optimum Moisture Content & $21 \%$ \\
\hline Maximum Dry Density & $15.91 \%$ \\
\hline
\end{tabular}

Table- II: Properties of stone aggregates

\begin{tabular}{|l|l|}
\hline Property & Value \\
\hline Specific Gravity & 2.66 \\
\hline Percentage fines $(\leq 0.075 \mathrm{~mm})$ & $0 \%$ \\
\hline Minimum size of aggregates & $2.5 \mathrm{~mm}$ \\
\hline Maximum size of aggregates & $10 \mathrm{~mm}$ \\
\hline D10 & $2.75 \mathrm{~mm}$ \\
\hline D30 & $4.3 \mathrm{~mm}$ \\
\hline D60 & $5.65 \mathrm{~mm}$ \\
\hline Cu & 2.05 \\
\hline Cc & 1.19 \\
\hline Classification (IS:1498-1970) & $\mathrm{GP}$ \\
\hline Angle of internal friction, ' $\phi '$ & $44.5^{\circ}$ \\
\hline
\end{tabular}

\section{TEST PROCEDURE}

A steel tank of diameter of $150 \mathrm{~mm}$ and height $230 \mathrm{~mm}$ was used to prepare soft soil bed of homogenous properties. The soil slurry was prepared by adding water to the dry soil equal to 1.5 times to its liquid limit and stirring the mix. This eliminated the voids and lumps from the soil. The slurry was then poured in to the mould where a brass perforated plate and a paper for filtration was kept at the bottom to allow drainage from the base. The soil was filled in layers, with care to maintain a mass of soil which is free from voids in the mould. After filling in mould, the soil has been kept in open air for 16 to 24 hours for self consolidation. A filter paper was kept on the top of soil bed to obstruct the soft soil entry towards upper side during loading. The brass perforated plate with a diameter $148 \mathrm{~mm}$ used as a footing kept on the upper portion of soft soil bed to allow the drainage from the top. The laboratory CBR testing machine was used for loading purpose on the soft soil bed (Fig. 2). A sustained load of 65 $\mathrm{kPa}$ has been applied on the top plate and maintained for 24 h.A sample of this soil was extracted from the mould to check the shear strength by vane shear test. The test bed prepared in this manner has shear strength of $7.5 \mathrm{kPa}$. This may be a practical ground situation of a soft soil bed. The stone column was constructed in this test bed by replacement method. For making the stone columns of different diameters, stainless steel thin pipes of internal diameter of 38.1, 50.8, 63.5 and $76.2 \mathrm{~mm}$ was used to pull out the soil. The stone were filled in layers of $25 \mathrm{~mm}$ from bottom to the top. Each layer was compacted by a tamping rod of $0.6 \mathrm{~kg}$ dropped from $100 \mathrm{~mm}$ height. The energy transferred by blows during installation of
The kaolin used as a soft soil bed for experimental work.

Table- I: Properties of kaolin

column increases the stiffness of column material and densify the nearby soil. The diameter of installed column is observed slightly larger than the pipe diameter used for extracting the soil.

After the construction of the stone column in the soil bed, desired load (pressure) was applied to study the settlement behavior of the composite soil.

The pressure was maintained for 24 hours. Settlement was recorded at different time intervals. The test beds were prepared for four stone column diameters (Fig.3) and in each of four different pressures were applied. The settlement behavior of the raw soil i.e. without stone column was also observed for these sustained pressures. The summary of tests is given in Table III.

Table-III: Summary of tests conducted

\begin{tabular}{|c|c|c|c|c|c|c|}
\hline $\begin{array}{c}\text { Soft soil bed } \\
\text { of average } \\
\text { undrained } \\
\text { shear } \\
\begin{array}{c}\text { strength of } \\
7.5 \mathrm{kPa}\end{array}\end{array}$ & $\begin{array}{c}\text { Stone } \\
\text { column } \\
\text { diameter }\end{array}$ & \multicolumn{4}{|c|}{$\begin{array}{c}\text { Applied pressure maintained for } \\
24 \text { hours }\end{array}$} & $\begin{array}{c}\text { No. } \\
\text { of } \\
\text { Tests }\end{array}$ \\
\cline { 2 - 7 }$(\mathrm{mm})$ & $\begin{array}{c}150 \\
\mathrm{kPa}\end{array}$ & $\begin{array}{c}200 \\
\mathrm{kPa}\end{array}$ & $\begin{array}{c}250 \\
\mathrm{kPa}\end{array}$ & $\begin{array}{c}300 \\
\mathrm{kPa}\end{array}$ & \\
\hline $\begin{array}{c}\text { Unreinforced } \\
\text { soil bed }\end{array}$ & - & 1 & 1 & 1 & 1 & 4 \\
\hline \multirow{2}{*}{$\begin{array}{c}\text { Reinforced } \\
\text { soil bed with } \\
\text { Stone }\end{array}$} & 39.5 & 1 & 1 & 1 & 1 & 4 \\
\cline { 2 - 7 } & 65.6 & 1 & 1 & 1 & 1 & 4 \\
\cline { 2 - 7 } Column & 77.2 & 1 & 1 & 1 & 1 & 4 \\
\hline
\end{tabular}

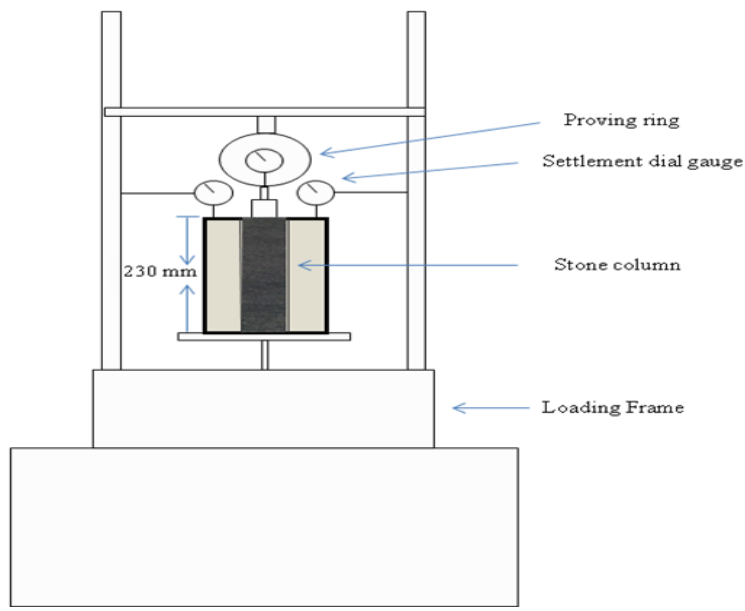

Fig.2. Loading arrangement

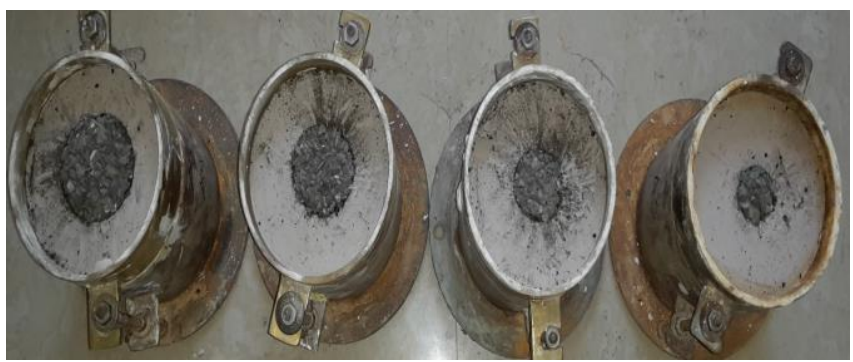

Fig.3. Installation of Stone columns of different diameters

Published By:

Blue Eyes Intelligence Engineering 


\section{TEST RESULTS}

\section{SETTLEMENT OF THE SOFT SOIL BED}

The settlement of the soft soil bed i.e. without stone column for sustained pressure of 150, 200, 250, $300 \mathrm{kPa}$ maintained for twenty four hours was recorded as 10.08 , $12.14,14.82$ and $16.39 \mathrm{~mm}$.

\section{EFFECT OF INSTALLING STONE COLUMN ON SETTLEMENT}

The settlements for the soft clay bed, the clay bed reinforced with the stone columns under different applied pressure are given in Fig. 4 to 7 . The figures show that the trend of settlement time behavior is similar under different applied pressures. The settlement in each case ceases after a certain time. This time is typically noted close to $24 \mathrm{hrs}$ in the observations. Further, the settlement is reduced for a constant sustained pressure, with expansion in the diameter of the stone column. The consolidation settlements noted from Fig. 4 to 7 are shown in Table IV.

Table -IV: Consolidation settlement of soft clay beds

\begin{tabular}{|c|c|c|c|c|c|}
\hline \multirow{2}{*}{$\begin{array}{c}\text { Type of test } \\
\text { bed }\end{array}$} & $\begin{array}{c}\text { Stone } \\
\text { column } \\
\text { diameter }\end{array}$ & \multicolumn{4}{|c|}{$\begin{array}{c}\text { Settlement at sustained load } \\
\text { maintained for 24 hours (mm) }\end{array}$} \\
\cline { 2 - 6 } & $(\mathrm{mm})$ & $\begin{array}{c}150 \\
\mathrm{kPa}\end{array}$ & $\begin{array}{c}200 \\
\mathrm{kPa}\end{array}$ & $\begin{array}{c}250 \\
\mathrm{kPa}\end{array}$ & $\begin{array}{c}300 \\
\mathrm{kPa}\end{array}$ \\
\hline $\begin{array}{c}\text { Unreinforced } \\
\text { soil bed }\end{array}$ & - & 10.08 & 12.14 & 14.82 & 16.39 \\
\hline \multirow{2}{*}{$\begin{array}{c}\text { Reinforced } \\
\text { soil bed with }\end{array}$} & 39.5 & 9.69 & 11.62 & 14.48 & 15.94 \\
\cline { 2 - 6 } \begin{tabular}{c} 
Stone Column \\
\cline { 2 - 6 }
\end{tabular} & 62.6 & 9.34 & 11.11 & 14.28 & 15.7 \\
\cline { 2 - 6 } & 77.2 & 8.76 & 10.45 & 13.52 & 15.21 \\
\hline
\end{tabular}

In order to show the effect of installation of stone column of different diameters on consolidation settlement, a parameter settlement reduction ratio (SRR) is used. SRR compares settlement of stone column reinforced soil to the untreated soil. It is given by:

$$
\mathrm{SRR}=\left\{\left(\mathrm{h}_{\mathrm{scb}}-\mathrm{h}_{\mathrm{rcb}}\right) / \mathrm{h}_{\mathrm{scb}}\right\} \times 100
$$

Where: $h_{\text {scb }}=$ settlement of the consolidated soft soil bed, $\mathrm{h}_{\mathrm{rcb}}=$ settlement of the soft soil bed reinforced with stone column.

The higher value of SRR is a measure of ground improvement. Its value for different test cases is indicated in Table. V.

Table -V: Effect of stone columns diameters on SRR

\begin{tabular}{|c|c|c|c|c|c|}
\hline \multirow{2}{*}{$\begin{array}{c}\text { Diameter } \\
\text { of stone } \\
\text { column }\end{array}$} & \multirow{2}{*}{$\begin{array}{c}\text { Area } \\
\text { Replacement }\end{array}$} & \multicolumn{4}{|c|}{$\begin{array}{c}\text { Settlement Reduction Ratio SRR (\%) } \\
\text { for sustained pressure of }\end{array}$} \\
\cline { 3 - 6 } & Ratio & $\begin{array}{c}150 \\
\text { kPa }\end{array}$ & $\begin{array}{c}200 \\
\text { kPa }\end{array}$ & $\begin{array}{c}250 \\
\text { kPa }\end{array}$ & $\begin{array}{c}300 \\
\text { kPa }\end{array}$ \\
\hline 39.5 & 6.93 & 3.86 & 4.28 & 2.29 & 2.74 \\
\hline 52.6 & 12.29 & 7.34 & 8.48 & 3.64 & 4.2 \\
\hline 65.5 & 19.06 & 13.09 & 13.92 & 8.77 & 7.19 \\
\hline 77.2 & 26.49 & 16.76 & 18.78 & 14.91 & 11.53 \\
\hline
\end{tabular}

Thus it may be noted that for a given applied sustained pressure, SRR increases with the diameter (or area replacement ratio) of the stone column.

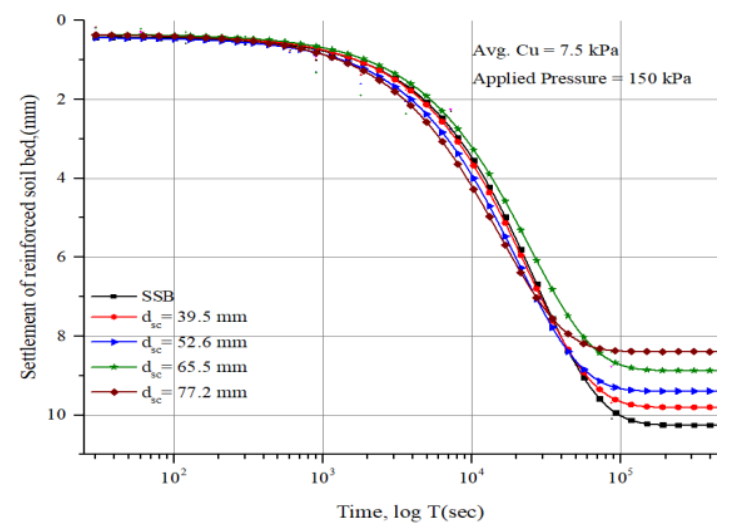

Fig.4. Settlement vs time for applied pressure $150 \mathrm{kPa}$

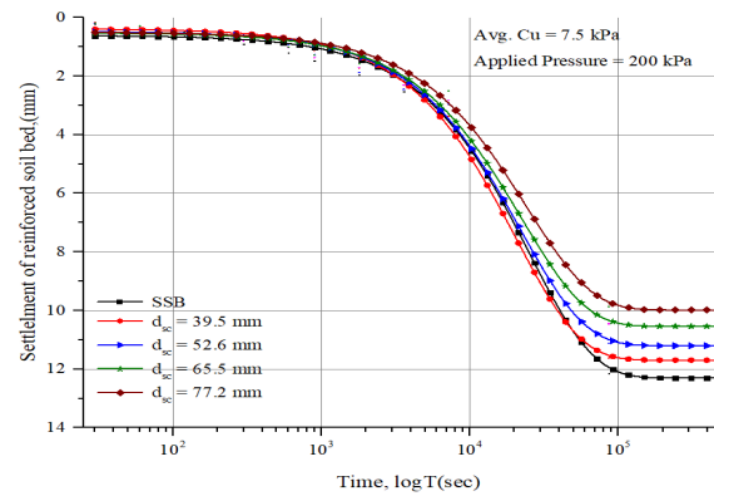

Fig.5. Settlement vs time for applied pressure $200 \mathrm{kPa}$

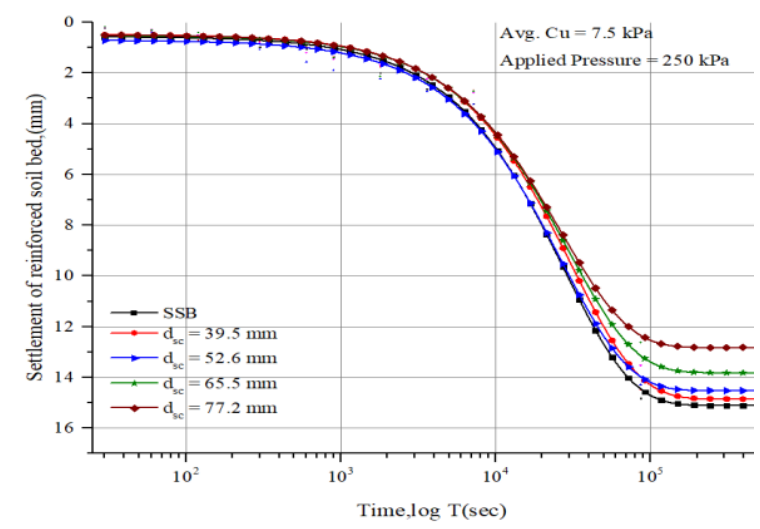

Fig.6. Settlement vs time for applied pressure $250 \mathrm{kPa}$

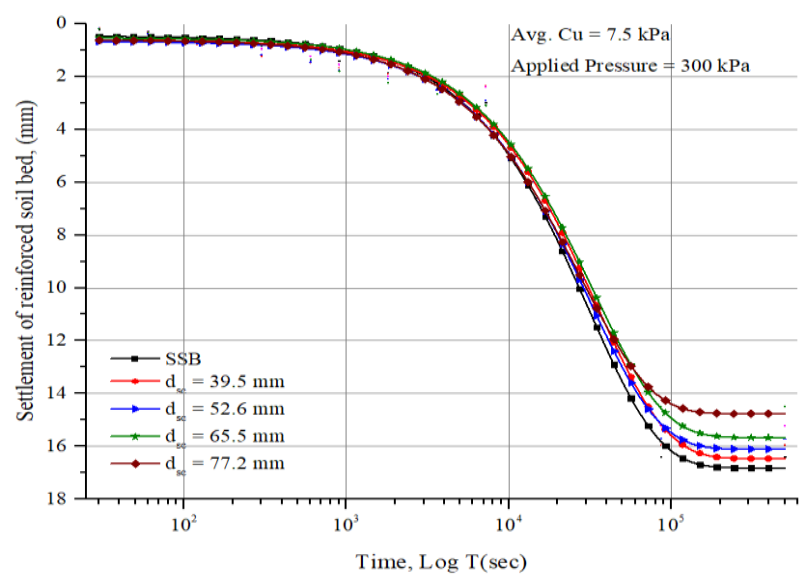

Fig.7. Settlement vs time for applied pressure $300 \mathrm{kPa}$ 


\section{SETTLEMENT PREDICTION OF STONE COLUMN REINFORCED SOIL}

The consolidation settlement of the soft soil treated ground with stone column, S, can be predicted by the procedure given in IS 15284(Part-1): 2003.

$$
\begin{aligned}
& \mathrm{S}=\mathrm{m}_{\mathrm{v}} \sigma \mathrm{H} \mu_{\mathrm{g}} \quad \text { OR } \\
& \mathrm{S}=\left[\left\{(\mathrm{Cc} H) /\left(1+\mathrm{e}_{0}\right)\right\} \log _{10}\left\{\left(\sigma_{0}+\Delta \sigma\right) / \sigma_{0}\right\}\right] \mu_{\mathrm{g}}
\end{aligned}
$$

Where, $\mathrm{m}_{\mathrm{v}}=$ Modulus of volume decrease of soil, $\sigma=$ Vertical pressure in surrounding ground, $\mathrm{H}=$ Thickness of treated soil, $\mathrm{Cc}=$ Compression index, $\mathrm{e}_{\mathrm{o}}=$ Initial void ratio,

$\sigma_{0}=$ The overburden pressure in the surrounding ground, $\Delta \sigma=$ Total applied pressure. $\mu_{\mathrm{g}}=$ settlement reduction factor $=\left[1 /\left\{1+(n-1) a_{s}\right\}\right], n=$ Stress concentration ratio (ratio between the stress in columns to stress in surrounding ground). It varies between 1.5 to 5 as suggested by Barksdale and Bachus [7]. The observed values of consolidation settlement in the present experimental study are compared with the theoretical values predicted by IS 15284 Part I is presented in Table VI.

In theoretical calculations input values of different parameters are taken as:

$\mathrm{a}_{\mathrm{s}}=$ Area replacement ratio (6.93\% for diameter of $38.1 \mathrm{~mm}$ stone column). $\mu_{\mathrm{g}}=0.9665$ (for, $\mathrm{n}=1.5$, taken as per area replacement ratio).The compression index, $\mathrm{Cc}_{c}=0.14$. The thickness of treated soil, $\mathrm{H}=208 \mathrm{~mm}$ at the beginning of pressure application. The initial void ratio, $\mathrm{e}_{\mathrm{o}}=0.85$. The overburden pressure in the surrounding ground, $\sigma_{0}=18.76$ $\mathrm{kPa}$. The applied pressure, $\Delta \sigma=150 \mathrm{kPa}$ is maintained for 24 hours.

The settlement ' $\mathrm{S}$ ' value has been found $14.49 \mathrm{~mm}$. The settlement values for stone column diameter $39.5 \mathrm{~mm}$ have been determined for different applied pressure of 200, 250, $300 \mathrm{kPa}$ was $15.65,16.40$ and $16.44 \mathrm{~mm}$ respectively. The experimental and numerical results were compared also for other diameters and given in Table VI.

\begin{tabular}{|c|c|c|c|c|c|c|c|c|}
\hline \multirow{4}{*}{$\begin{array}{l}\text { A.P. } \\
(\mathrm{kPa})\end{array}$} & \multicolumn{8}{|c|}{$\begin{array}{c}\text { Experimental and predicted consolidation settlement in } \mathrm{mm} \text { for test beds } \\
\text { having stone columns of diameter }\end{array}$} \\
\hline & \multicolumn{2}{|c|}{$39.5 \mathrm{~mm}$} & \multicolumn{2}{|c|}{$52.6 \mathrm{~mm}$} & \multicolumn{2}{|c|}{$65.5 \mathrm{~mm}$} & \multicolumn{2}{|c|}{$76.2 \mathrm{~mm}$} \\
\hline & \multicolumn{2}{|c|}{$\mathrm{n}=1.5, \mu_{\mathrm{g}}=0.96$} & \multicolumn{2}{|c|}{$\begin{aligned} \mathrm{n} & =2.1, \mu_{\mathrm{g}} \\
& =0.88\end{aligned}$} & \multicolumn{2}{|c|}{$\begin{array}{c}\mathrm{n}=2.7, \mu_{\mathrm{g}}= \\
0.75\end{array}$} & \multicolumn{2}{|c|}{$\mathrm{n}=3.4, \mu_{\mathrm{g}}=.61$} \\
\hline & $\mathrm{SE}_{\mathrm{E}}$ & $\mathrm{S}_{\mathrm{T}}$ & $\mathrm{S}_{\mathrm{E}}$ & $\mathrm{S}_{\mathrm{T}}$ & $\mathrm{S}_{\mathrm{E}}$ & $\mathrm{S}_{\mathrm{T}}$ & $\mathrm{S}_{\mathrm{E}}$ & $\mathrm{S}_{\mathrm{T}}$ \\
\hline 150 & 9.69 & 14.49 & 9.34 & 13.2 & 8.76 & 11.32 & 8.39 & 9.16 \\
\hline 200 & 11.62 & 15.65 & 11.11 & 14.34 & 10.45 & 12.34 & 9.86 & 9.98 \\
\hline 250 & 14.48 & 16.4 & 14.28 & 14.96 & 13.52 & 12.88 & 12.61 & 10.46 \\
\hline 300 & 15.94 & 16.44 & 15.7 & 15.08 & 15.21 & 13.01 & 14.5 & 10.55 \\
\hline
\end{tabular}

Table- VI: Comparison of settlement by experimental and theoretical calculations

A.P.-Applied Pressure, S.C.R. 'n'- Stress Concentration Factor,

S.R.F. ' $\mu_{\mathrm{g}}$ ' - Stress Reduction Factor.

The variation in consolidation settlement predicted by the procedure given in IS 15284 to the experimental value is determined by the relation

\% Variation $=\left[\left\{\left(\mathrm{S}_{\mathrm{E}}-\mathrm{S}_{\mathrm{T}}\right) / \mathrm{S}_{\mathrm{E}}\right\}\right] \mathrm{X} 100$ and is given in Table VII.

Table- VII: Variation in consolidation settlement between experimental and theoretical values for stone column reinforced soft soil beds

Diameter of $\quad$ \% variation in experimental and predicted consolidation \begin{tabular}{l|l} 
column $(\mathrm{mm})$ & settlement of the stone column reinforced test beds for
\end{tabular}

\begin{tabular}{|c|c|c|c|c|}
\hline \multirow{2}{*}{} & \multicolumn{4}{|c|}{ Applied Pressure $(\mathrm{kPa})$} \\
\cline { 2 - 5 } & 150 & 200 & 250 & 300 \\
\hline 39.5 & $-49.5 \%$ & $-34.68 \%$ & $-13.25 \%$ & $-3.13 \%$ \\
\hline 52.6 & $-41.3 \%$ & $-29.07 \%$ & $-4.76 \%$ & $4.11 \%$ \\
\hline 65.5 & $-29.22 \%$ & $-18.08 \%$ & $4.73 \%$ & $14.46 \%$ \\
\hline 76.2 & $-9.1 \%$ & $1.2 \%$ & $17.40 \%$ & $27.27 \%$ \\
\hline
\end{tabular}

From the Table VII, it may be noted that \% variation in settlement prediction by theoretical procedure is $\pm 50 \%$; which may be regarded as large variation. For narrowing the gap, it is necessary to revise the theoretica l procedure. The stress concentration factor adopted in theoretical evaluation is based on the recommendation of Barksdale and Bachus (1983) and is stated varying with area replacement ratio.

In order to enhance the performance of stone column in terms of load bearing and settlement; geogrids are used. The inclusion of geogrid changes the stiffness of the column material and is expected to give high SRR. Effect of stone column stiffness on the value of " $n$ " along with area replacement ratio may perhaps bring the theoretical prediction close to the experimental values.

\section{CONCLUSIONS}

The settlement behavior of soft clay treated with stone columns was studied under different sustained pressure. The experimental results have compared to the settlement analysis formula given by Barksdale and Bachus and IS 15284(Part-1): 2003. The conclusions from the study are given below:

(1) The effect of stone column installation on settlement reduction was expressed by a parameter SRR. Higher values of SRR are indicative of ground improvement. SRR is found increasing with the diameter of the stone column.

(2) The theoretical prediction of settlement by IS 15284 Part 1 procedure was compared with the experimental results. The variation in theoretical and experimental values is $\pm 50 \%$; and regarded as large.

(3) The theoretical procedure uses " $n$ " which at present suggested depending on area replacement ratio only. Its variation with column stiffness material needs to be studied to refine the theoretical procedure.

\section{REFERENCES}

1. Aboshi, H., Ichimoto, E., Enoki, M., \& Harada, K. (1979). The Compozer - a method to improve characteristics of soft clays by inclusion of large diameter sand columns. Proc. Int. Conf. on Soil Reinforcement: Reinforced Earth and Other Techniques, 1, 211-216.

2. Alamgir, M., Miura, N., Poorooshasb, H. B., \& Madhav, M. R. (1996). Deformation analysis of soft ground reinforced by columnar inclusions. Computers \& Geotechnics, 18(4), 267-290.

3. Ambily, A.P. and Gandhi, S.R. 2004.Experimental and theoretical evaluation of stone column in soft clay, Proceedings of International Confer-ence on Geotechnical and Geoenvironmental Engineering, Mumbai, 201-206.

4. Ambily, A.P. and Gandhi, S.R. 2007. Behavior of stone columns based on experimental and FEM analysis, Journal of Geotechnical and Geoenvironmental Engineering, ASCE, 133, (4): 405-415.

5. Babu, M.R.D., Shivashankar, R. and Nayak, S., Load settlement behavior of stone columns with circumferential nails, Indian Geotechnical Conference, GEOtrendz (2010) 579-582.

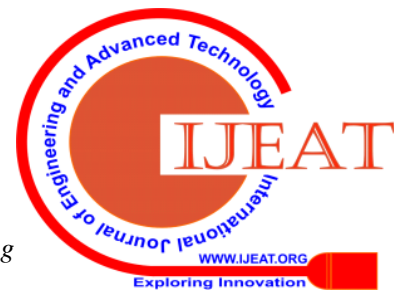


6. Balaam, N. P., \& Booker, J. R. (1985). Effect of stone column yield on settlement of rigid foundations in stabilized clay. International Journal of Numerical and Analytical Methods in Geomechanics, 9(4), 331-351.

7. Barksdale, R. D., and Bachus, R. C. (1983). "Design and construction of stone columns: Volume 1" Rep. No. FHWA/RD-83/026, Federal Highway Administration, Washington DC, US.

8. Baumann, V., \& Bauer, G. E. A. (1974). The performance of foundations on various soils stabilized by the vibro-compaction method. Canadian Geotechnical Journal, 11(4), 509-530.

9. Black, J. A., Sivakumar, V. and Bell, A. 2011. The settlement performance of stone column foundations, Géotechnique, 61, (11): 909 - 922 .

10. Borges, J. L., Domingues, T. S., \& Cardoso, A. S. (2009) Embankments on soft soil reinforced with stone columns - numerical analysis and proposal of a new design method. Geotechnical and Geological Engineering, 27(6), 667-679.

11. Chandrawanshi, S., Kumar, R. and Jain, P.K. 2017. Settlement characteristics of soft clay reinforced with stone column: An experimental small scale study, International Journal of Civil Engineering and Technology, 8, (5): 937-948.

12. Cimentada, A., Costa, A. D., Canizal, J. And Sagaseta, C. 2010. Laboratory study on radial consolidation and deformation in clay reinforced with stone columns, Canadian Geotechnical Journal, 48, pp. 36-52.

13. Dehariya, S., R. Kumar and Jain P.K., Load-settlement behaviour of granular pile in unsaturated and saturated expansive soil, International Journal of Advanced Engineering Research and Studies 3 (2014) 122-124.

14. Ellouze, S., Bouassida, M., Hazzar, L., \& Mroueh, H. (2010). On settlement of stone column foundation by Priebe's method. Ground Improvement, 163(GI2), 101-107.

15. Isaac, D.S. and Girish, M.S. Suitability of different materials for stone column construction, Electronic Journal of Geotechnical Engineer-ing 14 M (2009) 1-12

16. IS: 1498. 2007. Classification and identification of soils for general engineering purposes, New Delhi, Indian Standards Institution.

17. IS: 15284 Part 1. 2003. Indian standard code of practice for design and construction for ground improvement-guidelines, New Delhi, Indian Standards Institution.

18. Kumar, R. and Jain, P.K. Expansive soft soil improvement by geogrid encased granular pile, International Journal on Emerging Technologies 4 (2013) 55-61.

19. Madhav, M. R., \& Miura, N. (1994). Stone columns. XIII Int. Conf. on Soil Mech. and Foundation Eng., New Delhi, India, 163-164.

20. McCabe, B. A., Nimmons, G. J. and Egan, D. 2009. A review of field performance of stone columns in soft soils, Proceedings of the Institution of Civil Engineers-Geotechnical Engineering, 162, (6): 323-334.

21. Mitchell, J. K. and Huber, T. R. 1985. Performance of a stone column foundation, Journal of Geotechnical and Geoenvironmental Engineering, 111, (2): 205-223.

22. Priebe HJ (1976) Estimating settlements in a gravel column consolidated soil. Die Bautechnik 53(5): 160-162 .

23. Rajput, D., Kumar, R., Jain, P. K. And Chandrawanshi, S. 2016. Loadsettlement behaviour of soft soil reinforced with sand piles, International Research Journal of Engineering and Technology,3 ,(11): 1308-1313

24. Ranjan, G. 1989. Ground treated with granular piles and its response under load, Indian Geotechnical Journal 19, (1): 1-86.

25. Rangeard, D., Phan, P. T. P., Martinez, J. and Lambert, S. 2016 Mechanical behavior of fine-grained soil reinforced by sand columns: an experimental laboratory study, Geotechnical Testing Journal, 39, (4): 648-657

26. Shivashankar, R., Babu, M.R.D. and Nayak, S. Experimental studies on behaviour of stone columns in layered soils, Geotechnical and Geo-logical Engineering 29 (2011) 749-757.

27. Shahu, J. and Reddy, Y. 2011. Clayey soil reinforced with stone column group: model tests and analyses, Journal of Geotechnical and Geoenvironmental Engineering, 137, (12): 1265-1274.

28. Van Impe, W. F., \& De Beer, E. (1983). Improvement of settlement behavior of soft layers by means of stone columns. Proc. 8th European Conf. on Soil Mechanics and Foundation Engineering, Helsinki, Vol. 1, pp.309-312.

29. Zhang, L., Zhao, M., Shi, C., \& Zhao, H. (2012). Settlement calculation of composite foundation reinforced with stone columns. International Journal of Geomechanics.

\section{AUTHORS PROFILE}

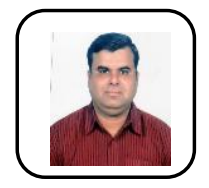

Mr. Sharad Kumar Soni is a research scholar in civil engineering department in Maulana Azad National Institute of Technology (MANIT), Bhopal, India. He received his Bachelor's degree in Civil Engineering and Master's degree in geotechnical engineering from MANIT Bhopal. His research area is mainly around ground improvement techniques such as stone column, geosynthetics, sof soil stabilization etc. He has more than 12 years of academic experience. He has participated in various seminars, conferences, workshop, and short term training programme. He has expertise in software like Plaxis 3D, Stadd Pro, OrginPro etc. 